\title{
Plant diversity effects on soil microbial functions and enzymes are stronger than warming in a grassland experiment
}

\author{
Katja Steinauer, ${ }^{1,2,7,8,9}$ David Tilman, ${ }^{3}$ Peter D. Wragg, ${ }^{3}$ Simone Cesarz, ${ }^{1,7,8}$ Jane M. Cowles, ${ }^{3}$ Karin Pritsch, ${ }^{4}$ \\ Peter B. Reich, ${ }^{5,6}$ Wolfgang W. Weisser, ${ }^{2}$ and Nico Eisenhauer ${ }^{1,2,7,8}$ \\ ${ }^{1}$ Friedrich Schiller University Jena, Institute of Ecology, Dornburger Strasse 159, 07743 Jena, Germany \\ ${ }^{2}$ Technische Universität München, Department of Ecology and Ecosystem Management, Hans-Carl-von-Carlowitz-Platz 2, \\ 85354 Freising, Germany \\ ${ }^{3}$ Department of Ecology, Evolution and Behavior, University of Minnesota, St. Paul, Minnesota 55108 USA \\ ${ }^{4}$ Institute of Soil Ecology, Helmholtz Zentrum München, German Research Center for Environmental Health $(\mathrm{GmbH})$, \\ Ingolstaedter Landstrasse 1, 85764 Neuherberg, Germany \\ ${ }^{5}$ Department of Forest Resources, University of Minnesota, 1530 Cleveland Avenue North, St. Paul, Minnesota 55108 USA \\ ${ }^{6}$ Hawkesbury Institute for the Environment, University of Western Sydney, Penrith, New South Wales 2753 Australia
}

Abstract. Anthropogenic changes in biodiversity and atmospheric temperature significantly influence ecosystem processes. However, little is known about potential interactive effects of plant diversity and warming on essential ecosystem properties, such as soil microbial functions and element cycling. We studied the effects of orthogonal manipulations of plant diversity (one, four, and 16 species) and warming (ambient, $+1.5^{\circ} \mathrm{C}$, and $+3^{\circ} \mathrm{C}$ ) on soil microbial biomass, respiration, growth after nutrient additions, and activities of extracellular enzymes in 2011 and 2012 in the BAC (biodiversity and climate) perennial grassland experiment site at Cedar Creek, Minnesota, USA. Focal enzymes are involved in essential biogeochemical processes of the carbon, nitrogen, and phosphorus cycles. Soil microbial biomass and some enzyme activities involved in the $\mathrm{C}$ and $\mathrm{N}$ cycle increased significantly with increasing plant diversity in both years. In addition, 16-species mixtures buffered warming induced reductions in topsoil water content. We found no interactive effects of plant diversity and warming on soil microbial biomass and growth rates. However, the activity of several enzymes (1,4- $\beta$-glucosidase, 1,4- $\beta$ - $\mathrm{N}$-acetylglucosaminidase, phosphatase, peroxidase) depended on interactions between plant diversity and warming with elevated activities of enzymes involved in the $\mathrm{C}, \mathrm{N}$, and $\mathrm{P}$ cycles at both high plant diversity and high warming levels. Increasing plant diversity consistently decreased microbial biomass-specific enzyme activities and altered soil microbial growth responses to nutrient additions, indicating that plant diversity changed nutrient limitations and/or microbial community composition. In contrast to our expectations, higher plant diversity only buffered temperature effects on soil water content, but not on microbial functions. Temperature effects on some soil enzymes were greatest at high plant diversity. In total, our results suggest that the fundamental temperature ranges of soil microbial communities may be sufficiently broad to buffer their functioning against changes in temperature and that plant diversity may be a dominant control of soil microbial processes in a changing world.

Key words: aboveground-belowground interactions; biodiversity-ecosystem functioning; extracellular enzymes; global change; grassland ecosystem; microbial biomass; plant diversity; warming.

\section{INTRODUCTION}

Since the late 19th century, the global surface temperature has increased by about $0.85^{\circ} \mathrm{C}$ due to human activities, such as fossil fuel combustion and land-use change (IPCC 2013). Temperature is one of the

Manuscript received 15 January 2014; revised 5 May 2014; accepted 6 June 2014; final version received 10 July 2014. Corresponding Editor: M. C. Rillig.

7 Present address: German Centre for Integrative Biodiversity Research (iDiv) Halle-Jena-Leipzig, Deutscher Platz 5e, 04103 Leipzig, Germany.

${ }_{8}$ Present address: Institute for Biology, University of Leipzig, Johannisallee 21, 04103 Leipzig, Germany.

${ }^{9}$ E-mail: katja.steinauer@web.de key factors impacting biochemical processes in terrestrial ecosystems (Rustad et al. 2001). Changes in atmospheric temperature are likely to increase drought periods and alter soil conditions like soil temperature and moisture (Wan et al. 2002). These changes can, in turn lead to changing soil respiration rates (Schindlbacher et al. 2012), litter decomposition (Liski et al. 2003) and nitrogen (N) mineralization (Larsen et al. 2010). Importantly, the effect of warming on ecosystem processes is likely to depend on the interplay with other co-occurring global changes, such as changes in plant community diversity and composition due to, for example, associated changes in plant community traits (Butenschoen et al. 2011). 
Research in the last two decades prompted a paradigm change in ecology by showing that biodiversity is not only the result of ecosystem processes, including those influenced by global change, but is also an important driver of ecosystem functions and services itself (Cardinale et al. 2011, Hooper et al. 2012). Alterations in plant diversity affect aboveground ecosystem functions (Tilman et al. 2001, Cardinale et al. 2011), but may also have an impact on belowground processes (Hooper et al. 2000, Zak et al. 2003, Tilman et al. 2006). To our knowledge, no field study has investigated interactive effects of plant diversity and warming on soil microbial processes. Because soil microorganisms can impact many ecosystem processes (van der Heijden et al. 2008), a better understanding of soil microbial responses to warming and changing plant diversity may provide important insights into the mechanisms by which both warming and diversity affect ecosystem functioning.

Previous studies showed that the biomass and activity of soil microorganisms increase significantly with increasing plant diversity (Stephan et al. 2000, Chung et al. 2007, Eisenhauer et al. 2013). Plant diversity enhanced net primary productivity, soil carbon inputs via exudation and turnover of plant biomass, and soil microbial biomass (Zak et al. 2003). Different plant species release different organic compounds that change rhizosphere conditions and affect microbial community structure, abundance, and activity (Sørensen 1997). In particular, plant community composition (e.g., plant functional group composition) can alter the activity of extracellular enzymes (Kreyling et al. 2008). These enzymes produced mainly by soil microorganisms and, to a lesser extent, by plant roots, degrade polymeric substances (e.g., cellulose, chitin, lignin) into accessible subunits (e.g., sugar, amino acids, ammonium, phosphate) for metabolism and growth of soil microorganisms and plants, respectively (Sinsabaugh et al. 1994, Sanaullah et al. 2011).

Due to the high energy and nutrient costs for the production of extracellular enzymes, soil microorganisms have to act in an economical way (Allison et al. 2011). Thus, enzyme production by soil microorganisms is regulated by their demand and by substrate availability, which in turn is affected by several factors, such as temperature and soil water content (Burns et al. 2013). Thus, changes in the soil microclimate, induced by different global change agents, may affect enzyme activities by biological (enzyme production, degradation) and chemical factors (inhibition, reduced diffusion), already within short time periods. Several studies have found that $\mathrm{N}$-degrading enzymes have lower temperature sensitivities than C-degrading enzymes (Wallenstein et al. 2009, 2012, Stone et al. 2012), which could result in a stoichiometric impairment of $\mathrm{N}$ degrading vs. C-degrading processes (Sinsabaugh et al. 2009). Conditions of low soil water availability, such as caused by warming-induced soil water shortage (Buten- schoen et al. 2011), could in addition lead to diffusion limitations of enzymes and substrates (Stark and Firestone 1995, Allison 2005). Studying the enzymatic activity in soil samples may thus yield important insights into the effects of increasing temperatures and changes in plant diversity on the functioning of soil microbial communities (Kandeler et al. 1999, Burns et al. 2013).

The effects of plant diversity on several soil microbial processes at the community level may be more pronounced in the presence of environmental stress, such as warming or drought, due to the buffering capacity of trait dissimilarity in multispecies assemblages (Ives and Carpenter 2007). Generally, soil water availability is a major control of soil microbial biomass. In species-rich plant communities, often lower evapotranspiration due to shading and a more stable microclimate under elevated plant shoot biomass have been reported to lead to a higher water content in the topsoil than species-poor ones $(0-15 \mathrm{~cm}$ [Caldeira et al. 2001], 0-6 cm [Eisenhauer et al. 2013], 0-15 cm [Vogel et al. 2013]); although neutral plant diversity effects have also been found (Spehn et al. 2000). Consequently, increased soil water content in the topsoil of higher plant diversity communities may reduce the negative effect of warming-induced water limitations on soil microbial functions. Given those interrelationships between the studied co-occurring global change drivers, we expected significant interactive effects on soil microbial functions, which may provide important insights into potential future changes in soil processes.

We studied soil microbial biomass and functioning, specifically the activities of seven soil extracellular enzymes involved in the $\mathrm{C}, \mathrm{N}$, and $\mathrm{P}$ cycles, in experimental manipulations of plant diversity (one, four, and 16 species) and temperature (ambient $+0^{\circ} \mathrm{C}$, $+1.5^{\circ} \mathrm{C}$, and $+3^{\circ} \mathrm{C}$ ). We investigated soil samples from the perennial grassland experiment BAC (biodiversity and climate) in east-central Minnesota, USA, taken during the peak growing season in 2011 and 2012. We hypothesized that (1) increasing plant diversity leads to increasing soil microbial biomass and enzyme activity, (2) higher temperature decreases soil microbial biomass and enzyme activity, and (3) higher plant diversity buffers effects of elevated temperature on soil microbial biomass and enzyme activity.

\section{Materials and Methods \\ Experimental design}

The present study took place in the BAC experiment site established at the Cedar Creek Ecosystem Science Reserve, Minnesota, USA. The site occurs on a glacial outwash plain with sandy soils. Mean temperature during the growing season (April-September) was $15.9^{\circ} \mathrm{C}$ in 2011 and $17.1^{\circ} \mathrm{C}$ in 2012 . Precipitation during the growing season was $721 \mathrm{~mm}$ in 2011. The growing season in 2012 was considerably drier, with $545 \mathrm{~mm}$ rainfall. 
Experimental plots $(9 \times 9 \mathrm{~m})$ were planted in 1994 and 1995 with different plant communities spanning a plant diversity gradient of one, four, and 16 species, which were randomly chosen from the species listed below (Tilman et al. 2001). The grassland prairie species belonged to one of five plant functional groups: $\mathrm{C}_{3}$ grasses (Agropyron smithii Tydb., Elymus canadensis L., Koeleria cristata (Ledeb.) Schult., Poa pratensis L.), $\mathrm{C}_{4}$ grasses (Andropogon gerardii Vitman., Panicum virgatum L., Schizachyrium scoparium (Michx.) Nash, Sorghastrum nutans (L.) Nash), legumes (Amorpha canescens Pursh., Lespedeza capitata Michx., Lupinus perennis L., Petalostemum purpureum (Vent.) Rydb., Petalostemum villosum Spreng.), nonlegume forbs (Achillea millefolium L., Asclepias tuberosa L., Liatris aspera Michx., Monarda fistulosa L., Soldidago rigida L.), and woody species (Quercus ellipsoidalis E. J. Hill, Quercus macrocarpa Michx.). The individuals of those two woody species (Quercus spp.), which were small in size and rare because of low survival, were removed from all plots in which they occurred in 2010.

In addition to the manipulation of plant diversity, the plots were divided into three subplots $(2.5 \times 3.0 \mathrm{~m})$. Heat treatments were applied from March to November each year, beginning in 2009, using infrared lamps $1.8 \mathrm{~m}$ aboveground emitting $600 \mathrm{~W}$ (which caused a $1.5^{\circ} \mathrm{C}$ increase in soil temperature for vegetation-free soils) and $1200 \mathrm{~W}$ (which caused a $3^{\circ} \mathrm{C}$ increase; Valpine and Harte 2001, Kimball 2005, Whittington et al. 2013) to increase the surface soil temperature of each subplot (see Plate 1). To account for possible shading effects, metal flanges and frames were hung over control subplots. An average across all vegetated plots, temperature manipulations elevated soil temperature at $1 \mathrm{~cm}$ depth by $1.18^{\circ} \mathrm{C}$ in the low warming $\left(+1.5^{\circ} \mathrm{C}\right)$ treatment and by $2.69^{\circ} \mathrm{C}$ in the high warming $\left(+3^{\circ} \mathrm{C}\right)$ treatment, and at $10 \mathrm{~cm}$ depth temperature by $1.00^{\circ} \mathrm{C}$ in the low warming $\left(+1.5^{\circ} \mathrm{C}\right)$ treatment and by $2.16^{\circ} \mathrm{C}$ in the high warming $\left(+3^{\circ} \mathrm{C}\right)$ treatment.

Soil samples of three subplots in each of 27 experimental plots were taken; due to technical difficulties we could only analyze 66 samples out of 81 existing subplots (monoculture, 10 replicates in ambient $+0^{\circ} \mathrm{C}$ treatment, eight replicates in $+1.5^{\circ} \mathrm{C}$ treatment, nine replicates in $+3^{\circ} \mathrm{C}$ treatment; four species mixture, six replicates in ambient $+0^{\circ} \mathrm{C}$ treatment, six replicates in $+1.5^{\circ} \mathrm{C}$ treatment, seven replicates in $+3^{\circ} \mathrm{C}$ treatment; 16 species mixture, six replicates in ambient $+0^{\circ} \mathrm{C}$ treatment, six replicates in $+1.5^{\circ} \mathrm{C}$ treatment, eight replicates in $+3^{\circ} \mathrm{C}$ treatment).

The BAC plots are a representative subset of the plots in the biodiversity experiment E120 at Cedar Creek, which were assembled as random draws of a given number of species from the species pool (Zak et al. 2003). Given low heterogeneity of soil abiotic conditions at the start of the experiment, the experiment was not blocked.

\section{Soil sampling}

Soil samples were taken in August 2011 and 2012 (peak of the growing season) for soil microbial measurements and enzyme assays. From each subplot, nine (2011) or six (2012) soil samples were taken to a depth of $20 \mathrm{~cm}$ using a metal corer (diameter $2 \mathrm{~cm}$ ) and pooled per subplot in a plastic bag. The samples were sieved $(2 \mathrm{~mm})$ to remove large stones, roots, earthworms, and other invertebrates $>2 \mathrm{~mm}$, then stored at $-20^{\circ} \mathrm{C}$ until measurement of soil microbial properties. Soil temperature was measured in each subplot using iButtons (Maxim Integrated Products, Sunnyvale, California, USA) that recorded soil temperatures at $1 \mathrm{~cm}$ and $10 \mathrm{~cm}$ depths every hour throughout the 2012 growing season (April-September).

\section{Soil microbial measurements}

Approximately $4.5 \mathrm{~g}$ soil fresh mass was used to measure soil microbial biomass and growth after addition of different substrates containing potentially limiting elements, such as nitrogen and phosphorus. Using an automated respirometer based on electrolytic $\mathrm{O}_{2}$ microcompensation (Scheu 1992), soil microbial biomass was determined from the maximum initial respiratory response (MIRR) within the first 10 hours after the addition of D-glucose using the substrateinduced respiration method (SIR; Anderson and Domsch 1978). For this purpose the catabolic enzymes of soil microorganisms were saturated by adding $4 \mathrm{mg}$ glucose/g soil dry mass as an aqueous solution. Gravimetric soil water content was determined by drying the soil samples previously used for SIR measurements overnight at $60^{\circ} \mathrm{C}$ to constant weight and calculating the difference in weight between fresh and dried soil.

Furthermore, soil microbial growth was measured after glucose and nitrogen (CN) addition (supplied as $\left(\mathrm{NH}_{4}\right)_{2} \mathrm{SO}_{4}$, ammonium sulfate) at a $\mathrm{C}: \mathrm{N}$ ratio of 10:2 (Anderson and Domsch 1978). An aqueous solution $(500 \mu \mathrm{L} ; 4 \mathrm{mg}$ glucose $/ \mathrm{g}$ soil dry mass and $2.6 \mathrm{mg}$ ammonium sulfate/g soil dry mass) was added to each sample to adjust to equal water content in each sample. Additionally, soil microbial growth was examined after adding glucose and phosphorus (CP; supplied as $\mathrm{Na}_{2} \mathrm{HPO}_{4}$, sodium phosphate) at a C:P ratio of 10:1 (4 $\mathrm{mg}$ glucose $/ \mathrm{g}$ soil dry mass and $0.9 \mathrm{mg}$ sodium phosphate/g soil dry mass), as well as the combination of glucose, ammonium sulfate, and sodium phosphate (CNP; C:N:P, 10:2:1). Microbial growth rate was determined using the lowest reading of MIRR and highest value within the first $10 \mathrm{~h}$ (Eisenhauer et al. 2010). The respiration rates were log-transformed to account for the exponential growth of soil microorganisms after nutrient addition. Transformed respiration rates were plotted against time, and the slope of microbial growth was determined by linear regression (Eisenhauer et al. 2010). Due to the very sandy soil, we considered soil microorganisms to be primarily $\mathrm{C}$ 
limited, which is why we did not test microbial growth after addition of $\mathrm{N}$ and $\mathrm{P}$ without adding $\mathrm{C}$ (Eisenhauer et al. 2010).

\section{Extracellular enzyme activities}

The activities of seven soil enzymes were measured to get insights into microbial community function. The selected enzymes were cellobiohydrolase (EC 3.2.1.91), $\beta$-1,4-glucosidase (EC 3.2.1.21), 1,4,- $\beta$-N-acetylglucosaminidase (EC 3.2.1.52), acid phosphatase (EC 3.1.3.2), urease (Amidohydrolase; EC 3.5.1.5), phenol oxidase (Phenolox; EC 1.10.3.2), and peroxidase (Perox; EC 1.11.1.7). All of those enzymes are involved in cellulose and lignin decomposition and $\mathrm{N}$ and $\mathrm{P}$ mineralization in the litter layer and mineral soil horizons (Baldrian 2008). Four hydrolytic enzyme activities were measured using a fluorimetric method based on the release of methylumbelliferone (MU) from MU-labeled substrates. The enzyme cellobiohydrolase transforms cellulose into cellobiose, which is hydrolyzed by $\beta$-1,4-glucosidase to glucose. 1,4- $\beta$-N-acetylglucosaminidase hydrolyses $\mathrm{N}$ acetyl-D-hexosamine residues in $\mathrm{N}$-acetyl- $\beta$-D-hexosaminides such as chitin, and acid phosphatase acts on organic bound monophosphates. The absorbance of colorimetric enzyme reaction products of the oxidative enzymes phenol oxidase and peroxidase, both involved in lignin degradation, were measured spectrophotometrically using L-3,4-dihydroxy-phenylalanine as substrate. Urease hydrolyzing urea into carbon dioxide, and ammonia was measured by the use of urea as substrate. For fluorimetric enzyme assays (adapted to Saiya-Cork et al. [2002]), a sample suspension was prepared from $1 \mathrm{~g}$ of soil and $125 \mathrm{~mL}$ of $50 \mathrm{mM}$ sodium acetate buffer ( $\mathrm{pH}$ 5.0) and homogenized using an ultrasonic bath for $1 \mathrm{~min}$. According the $\mathrm{pH}$ value of the soil samples, the $\mathrm{pH}$ of 5.0 was chosen to maintain field conditions. We set up three replicates of sample wells with substrate, three replicate blank wells with buffer, and six negative ambient wells, including substrate and buffer, as well as a calibration curve, for each sample with standard concentrations of $0 \mu \mathrm{mol} / \mathrm{L}, 2.5 \mu \mathrm{mol} / \mathrm{L}, 5$ $\mu \mathrm{mol} / \mathrm{L}, 10 \mu \mathrm{mol} / \mathrm{L}$, and $20 \mu \mathrm{mol} / \mathrm{L}$, per assay. After incubation at $20^{\circ} \mathrm{C}$ in the dark for $2 \mathrm{~h}$, the fluorescence was measured at $365 \mathrm{~nm}$ excitation and $450 \mathrm{~nm}$ emission using a fluorescence microplate reader (SpectraMAX Gemini EM, Molecular Devices, Sunnyvale, California, USA).

Absorbance of the oxidative enzymes was determined using 96 wells plates, including three replicates of sample wells, six replicates of negative ambient wells, and three replicates of blank wells. The activities of phenol oxidase and peroxidase were measured at $450 \mathrm{~nm}$ and of urease at $610 \mathrm{~nm}$ after an incubation period of $18 \mathrm{~h}$ in the dark at $20^{\circ} \mathrm{C}$ using an absorbance microplate reader (SpectraMAX 340, Molecular Devices, Sunnyvale, California, USA). All soil enzyme activities were then expressed in nano moles per hour per gram of dry soil $\left(\mathrm{nmol} \cdot \mathrm{h}^{-1} \cdot \mathrm{g}^{-1}\right)$. Additionally, mass-specific enzyme activity (nmol activity $\cdot h^{-1} \cdot[\mu \mathrm{g} \text { microbial biomass carbon }]^{-1}$ ) was calculated by dividing the potential extracellular enzyme activity (EEA) by microbial biomass carbon (MBC; Steinweg et al., 2013).

Although, optimal conditions in terms of soil water content and temperature are given under laboratory conditions compared to field conditions, those measurements are still suitable to display fundamental responses to different treatments (plant diversity and temperature).

\section{Statistical analysis}

The whole data set comprising 66 samples per year was analyzed using general linear models (GLM) for a split-plot design for each year. The effects and interactions of plant diversity (one, four, and 16 species; log-transformed) and temperature (ambient $+0^{\circ} \mathrm{C},+1.5^{\circ} \mathrm{C}$, and $3^{\circ} \mathrm{C}$ ) on gravimetric soil water content (SWC), soil microbial biomass (Cmic), microbial growth after addition of glucose (C), glucose and ammonium nitrate $(\mathrm{CN})$, glucose and sodium phosphate (CP), all three substrates in combination (CNP), and extracellular enzymes ( $\beta$-1,4-glucosidase, cellobiohydrolase, $1,4,-\beta-\mathrm{N}$-acetylglucosaminidase, acid phosphatase, phenol oxidase, peroxidase, and urease) were tested (all log-transformed to meet the requirements for parametric statistical tests). Warming treatments were represented by subplots. Plant diversity and temperature were tested both as linear and categorical factors depending on the shape of the response of each dependent variable. Additionally, the effects of presence/absence of plant functional groups $\left(\mathrm{C}_{3}\right.$ and $\mathrm{C}_{4}$ grasses, legumes, nonlegume forbs, and woody species) were tested. The GLM analyses were implemented using the core functions within the $\mathrm{R}$ statistical environment ( $R$ Development Core Team 2013). Further, all variables were analyzed by a principal component analysis (PCA) for each year to explore and illustrate associations between variables. To compare response variables measured in different units, we standardized the response values via $z$ transformation. PCAs were performed using CANOCO software (Lepš and Šmilauer 2003; Microcomputer Power, Ithaca, New York, USA). The whole data set is shown in the Supplement.

\section{Results}

\section{Soil microbial measurements}

Soil microbial biomass increased significantly with increasing plant diversity in both years (monocultures to 16-plant species mixtures, $+122 \%$ and $+105 \%$ in 2011 and 2012, respectively; Fig. 1a; Table 1), but it was not significantly affected by temperature and respective interactions (all $P>0.1$ ). The presence of legumes positively affected soil microbial biomass in both years (2011, +91\%; 2012, +85\%). In 2011, microbial growth after addition of $\mathrm{C}$ decreased significantly with increasing plant diversity and marginally with temperature 

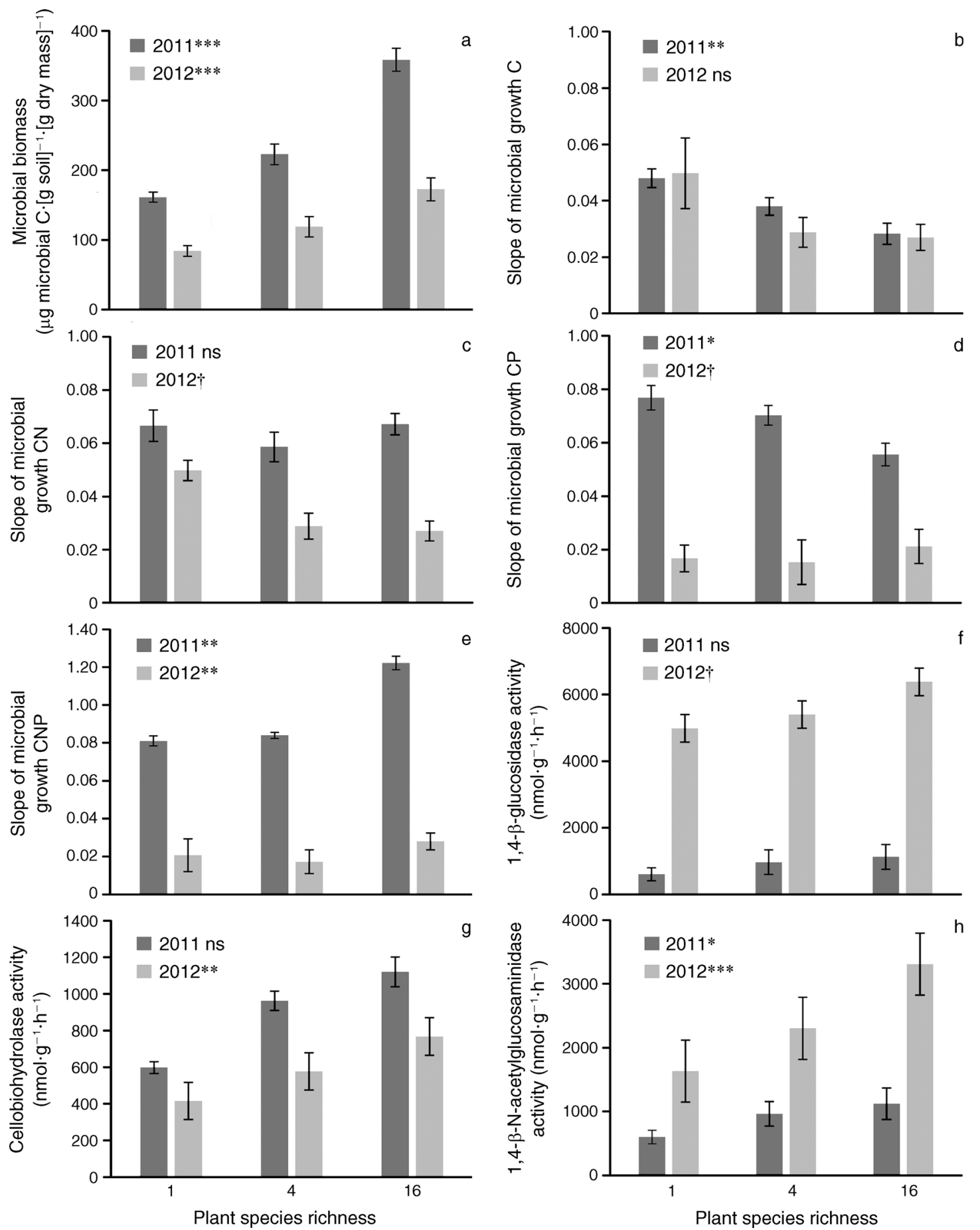

FIG. 1. Variations in (a) soil microbial biomass in 2011 (dark gray) and 2012 (light gray), (b) microbial growth (slope) after addition of glucose (C), (c) microbial growth (slope) after addition of carbon and nitrogen (CN), (d) microbial growth (slope) after addition of carbon and phosphorus (CP), (e) microbial growth (slope) after addition of carbon, nitrogen and phosphorus (CNP), (f) 1,4-B-glucosidase activity, (g) cellobiohydrolase activity, and (h) 1,4-B-N-acetylglucosaminidase activity as affected by plant diversity (one, four, and 16 plant species). Transformed respiration rates were plotted against time, and the slope of microbial growth was determined by linear regression (Eisenhauer et al. 2010). Values are means \pm SE.

$* * * P<0.001 ; * * P<0.01 ; * P<0.05 ; \dagger P<0.1 ;$ ns, not significant 
TABLE 1. GLM table for the effects of plant diversity (PD; 1,4 , and 16 plant species), temperature (TE; ambient, $+1.5^{\circ} \mathrm{C},+3^{\circ} \mathrm{C}$ ), and plant functional groups (presence and absence of $\mathrm{C}_{3}$ grasses, $\mathrm{C}_{4}$ grasses, legumes, forbs, and woody species) on microbial biomass (Cmic), microbial growth after the addition of glucose $(\mathrm{C})$, glucose and nitrogen $(\mathrm{CN})$, glucose and phosphorus $(\mathrm{CP})$, the combination of CNP, and soil water content (SWC) of (a) 2011 and (b) 2012.

\begin{tabular}{|c|c|c|c|c|c|c|c|c|c|c|c|c|c|}
\hline \multirow[b]{2}{*}{ Parameters } & \multirow[b]{2}{*}{$\mathrm{df}$} & \multicolumn{2}{|c|}{ Cmic } & \multicolumn{2}{|c|}{$\mathrm{C}$} & \multicolumn{2}{|c|}{$\mathrm{CN}$} & \multicolumn{2}{|c|}{$\mathrm{CP}$} & \multicolumn{2}{|c|}{$\mathrm{CNP}$} & \multicolumn{2}{|c|}{ SWC } \\
\hline & & $F$ & $P$ & $F$ & $P$ & $F$ & $P$ & $F$ & $P$ & $F$ & $P$ & $F$ & $P$ \\
\hline \multicolumn{14}{|l|}{2011} \\
\hline PD & 1,65 & 44.05 & $<\mathbf{0 . 0 0 0 1}$ & 9.45 & 0.005 & 0.15 & 0.699 & 6.27 & 0.020 & 12.08 & 0.002 & 0.20 & 0.660 \\
\hline TE & 1,65 & 0.46 & 0.503 & 3.31 & 0.077 & 2.88 & 0.098 & 3.13 & 0.085 & 1.44 & 0.238 & 0.00 & 0.995 \\
\hline $\mathrm{PD} \times \mathrm{TE}$ & 2,64 & 2.72 & 0.108 & 0.68 & 0.415 & 0.02 & 0.880 & 0.42 & 0.520 & 1.72 & 0.198 & 2.93 & 0.095 \\
\hline \multicolumn{14}{|c|}{ Plant functional groups } \\
\hline $\mathrm{C}_{3}$ grasses & 1,65 & 1.05 & 0.317 & 0.73 & 0.403 & 6.15 & 0.021 & 0.28 & 0.600 & 11.76 & $<\mathbf{0 . 0 0 0 1}$ & 0.53 & 0.473 \\
\hline $\mathrm{C}_{4}$ grasses & 1,65 & 1.99 & 0.172 & 2.58 & 0.123 & 3.66 & 0.069 & 0.21 & 0.651 & 0.71 & 0.408 & 0.87 & 0.361 \\
\hline Legumes & 1,65 & 7.70 & 0.011 & 2.32 & 0.142 & 0.05 & 0.829 & 0.04 & 0.845 & 2.41 & 0.135 & 0.02 & 0.896 \\
\hline Forbs & 1,65 & 0.47 & 0.501 & 0.44 & 0.515 & 0.10 & 0.750 & 1.04 & 0.318 & 0.10 & 0.761 & 0.04 & 0.854 \\
\hline Woody species & 1,65 & 0.43 & 0.517 & 0.02 & 0.902 & 0.47 & 0.500 & 0.22 & 0.645 & 0.09 & 0.773 & 0.79 & 0.384 \\
\hline Total error & 36 & & & & & & & & & & & & \\
\hline \multicolumn{14}{|l|}{2012} \\
\hline PD & 1,64 & 19.17 & $<\mathbf{0 . 0 0 0 1}$ & 2.22 & 0.150 & 3.61 & 0.070 & 3.20 & 0.087 & 8.14 & 0.009 & 0.67 & 0.421 \\
\hline TE & 1,64 & 2.09 & 0.156 & 2.61 & 0.115 & 0.17 & 0.684 & 0.00 & 0.968 & 0.48 & 0.492 & 44.62 & $<0.0001$ \\
\hline $\mathrm{PD} \times \mathrm{TE}$ & 2,63 & 0.78 & 0.382 & 1.43 & 0.240 & 0.06 & 0.815 & 0.08 & 0.780 & 0.61 & 0.441 & 4.27 & 0.046 \\
\hline \multicolumn{14}{|c|}{ Plant functional groups } \\
\hline $\mathrm{C}_{3}$ grasses & 1,64 & 2.60 & 0.121 & 0.97 & 0.334 & 0.51 & 0.483 & 2.72 & 0.113 & 1.05 & 0.316 & 0.03 & 0.859 \\
\hline $\mathrm{C}_{4}$ grasses & 1,64 & 1.43 & 0.244 & 0.01 & 0.942 & 4.56 & 0.044 & 0.51 & 0.481 & 0.28 & 0.599 & 0.07 & 0.800 \\
\hline Legumes & 1,64 & 5.63 & 0.027 & 1.59 & 0.221 & 0.41 & 0.528 & 0.44 & 0.516 & 0.36 & 0.556 & 1.55 & 0.227 \\
\hline Forbs & 1,64 & 0.70 & 0.412 & 0.35 & 0.561 & 1.40 & 0.249 & 0.68 & 0.420 & 2.13 & 0.158 & 0.46 & 0.505 \\
\hline Woody species & 1,64 & 0.11 & 0.745 & 7.64 & 0.011 & 0.00 & 0.968 & 2.24 & 0.148 & 0.51 & 0.484 & 0.37 & 0.557 \\
\hline Total error & 37 & & & & & & & & & & & & \\
\hline
\end{tabular}

Notes: Significant results $(P<0.05)$ are highlighted in bold and marginally significant results $(P<0.10)$ are given in bold and italics.

(Fig. 1b; Table 1). Furthermore, microbial growth after $\mathrm{C}$ addition was negatively affected by the presence of woody plant species in $2012(-21 \%$; Table 1). Soil microbial growth after the addition of $\mathrm{CN}$ showed a declining trend with increasing plant diversity in 2012 (Fig. 1c; Table 1). Moreover, microbial growth decreased in the presence of $\mathrm{C}_{3}$ grasses in $2011(-13 \%$; Table 1) and increased in the presence of $\mathrm{C}_{4}$ grasses in $2012(+24 \%$; Table 1). Microbial growth after the addition of CP significantly decreased with increasing plant diversity in 2011 (Fig. 1d; Table 1). Microbial growth after addition of CNP decreased from monocultures to 4-species mixtures followed by an increase to 16species assemblages in both years (Fig. 1e, Table 1). Additionally, microbial growth after the addition of CNP was increased in the presence of $\mathrm{C}_{3}$-grasses in 2011 $(+11 \%$; Table 1$)$.

Gravimetric soil water content was lower in August 2012 than in August 2011 (-30\%; Fig. 2a, b; Table 1) and decreased significantly with increasing temperature in August 2012 and by trend in 2011 (Fig. 2a, b; Table 1). Soil water content decreased with increasing temperature in plant monocultures and four species mixtures, while soil water content was stable in plant communities with 16 species in both years (Fig. 2a, b).

\section{Extracellular enzyme activity assays}

In general, single and interactive effects of plant diversity and temperature were found for several enzyme activities. Among enzymes involved in the $\mathrm{C}$ cycle, activity of 1,4- $\beta$-glucosidase showed increasing activity with increasing number of plant species in both years (Fig. 1f, Table 2). Besides that, it showed no significant response to increasing temperature in monocultures, but increased with increasing temperature in four- and 16-species mixtures in 2011 (Fig. 2c; Table 2). Additionally, mass-specific 1,4- $\beta$-glucosidase activity declined significantly in both years (Fig. 3a; Appendix). Cellobiohydrolase, which is mainly responsible for degradation of cellulose, showed significantly higher activity in species-rich plant communities than in species-poor ones in $2012(+85 \%$; Fig. 1g; Table 2) and decreased marginally significantly with increasing temperature $(-10 \%)$, whereas interactions had no significant effects. In addition, the mass-specific cellobiohydrolase activity decreased significantly with increasing plant diversity in both years (Fig. 3b; Appendix). Further, cellobiohydrolase activity was positively affected by the presence of $\mathrm{C}_{4}$ grasses in 2012 (+17\%; Table 2). 1,4- $\beta$-N-acetylglucosaminidase, an enzyme involved in the degradation of chitin, showed a significant increase with increasing plant diversity in both years (Fig. 1h; Table 2). Besides, it was not significantly affected by increasing temperature in monocultures, but increased significantly in four- and 16-species mixtures in 2011 with increasing temperature (Fig. 2d; Table 2). 

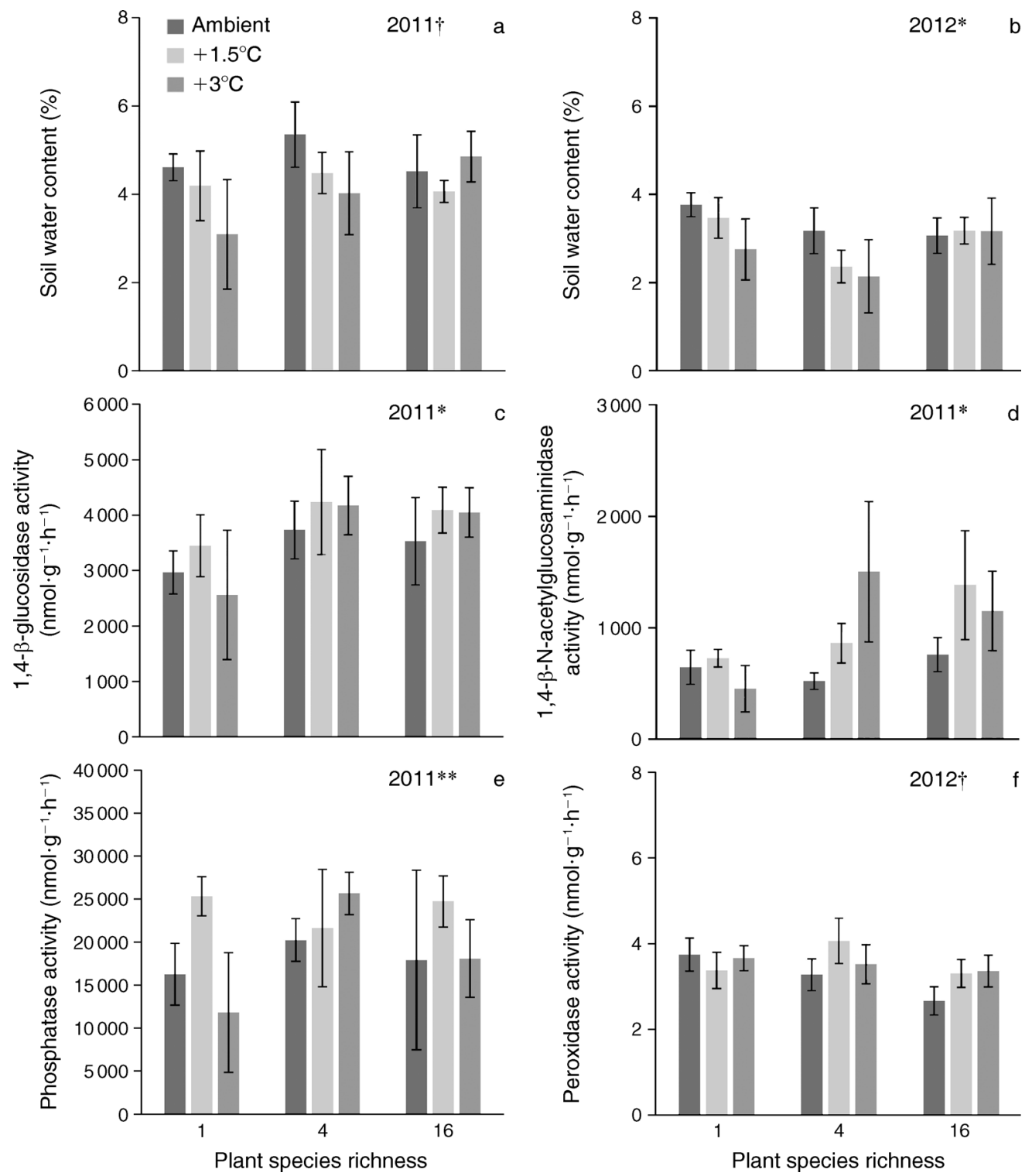

FIg. 2. Variations in soil water content in (a) 2011 and in (b) 2012, (c) 1,4-B-glucosidase activity, (d) 1,4-ß-Nacetylglucosaminidase activity, (e) phosphatase activity, and (f) peroxidase activity as affected by plant diversity (one, four, and 16 plant species) and temperature treatment (ambient $+0^{\circ} \mathrm{C}$ [dark gray], $+1,5^{\circ} \mathrm{C}$ [light gray], $+3^{\circ} \mathrm{C}$ [mid gray]). Values are means $\pm \mathrm{SE}$.

** $P<0.01 ; * P<0.05 ; \dagger P<0.1$.

The activity of phosphatase, an important enzyme involved in the $\mathrm{P}$ cycle, showed an increase in fourspecies mixtures with increasing temperature, but a hump-shaped response to increasing temperature in plant monocultures and 16-species mixtures in 2011 (Fig. 2e). Furthermore, mass-specific phosphatase activity decreased with increasing plant diversity in both years (Fig. 3c; Appendix).

Among enzymes involved in the $\mathrm{N}$ cycle and the degradation of lignin, peroxidase activity showed no significant response to increasing temperature in monocultures and four-species mixtures, whereas it increased with temperature in 16-species mixtures (Fig. 2f). Moreover, increasing plant diversity significantly decreased the mass-specific enzyme activity of peroxidase (Fig. 3d; Appendix). Besides, peroxidase activity was enhanced by the presence of legumes in 2011 $(+11 \%)$. The same was true for the presence of forbs in $2012(+16 \%)$. The activity of phenol oxidase increased significantly with increasing temperature in 2011 $(+40 \%$; Table 2). Mass-specific enzyme activity declined significantly with increasing plant species richness (Fig. 3e; Appendix). Further, phenol oxidase activity was increased in the presence of forbs $(+11 \%)$. The hydrolysis of urea, represented by urease activity was not significantly influenced by plant 
TABLE 2. GLM table for the effects of plant diversity (PD; one, four, and 16 plant species), temperature (TE; ambient $+0^{\circ} \mathrm{C}$, $+1.5^{\circ} \mathrm{C},+3^{\circ} \mathrm{C}$ ), and plant functional groups (presence and absence of $\mathrm{C}_{3}$ grasses, $\mathrm{C}_{4}$ grasses, legumes, forbs, and woody species) on microbial enzyme activity of 1,4- $\beta$-glucosidase, cellobiohydrolase, $1,4-\beta$-N-acetyl-glucosaminidase, phosphatase, peroxidase, phenol oxidase, and urease of (a) 2011 and (b) 2012.

\begin{tabular}{|c|c|c|c|c|c|}
\hline \multirow[b]{2}{*}{ Parameters } & \multirow[b]{2}{*}{ df } & \multicolumn{2}{|c|}{ 1,4-ß-glucosidase } & \multicolumn{2}{|c|}{ Cellobiohydrolase } \\
\hline & & $F$ & $P$ & $F$ & $P$ \\
\hline \multicolumn{6}{|l|}{2011} \\
\hline PD & 1.65 & 2.76 & 0.111 & 4.16 & 0.053 \\
\hline TE & 1.65 & 0.10 & 0.758 & 0.71 & 0.404 \\
\hline $\mathrm{PD} \times \mathrm{TE}$ & 2.64 & 6.98 & 0.012 & 0.07 & 0.791 \\
\hline \multicolumn{6}{|c|}{ Plant functional groups } \\
\hline $\mathrm{C}_{3}$ grasses & 1.65 & 0.25 & 0.622 & 0.43 & 0.519 \\
\hline $\mathrm{C}_{4}$ grasses & 1.65 & 0.39 & 0.537 & 1.43 & 0.245 \\
\hline Legumes & 1.65 & 0.91 & 0.352 & 0.03 & 0.873 \\
\hline Forbs & 1.65 & 0.79 & 0.383 & 0.01 & 0.924 \\
\hline Woody species & 1.65 & 0.03 & 0.860 & 0.13 & 0.721 \\
\hline Total error & $36,35^{\dagger}$ & & & & \\
\hline \multicolumn{6}{|l|}{2012} \\
\hline PD & 1.64 & 2.76 & 0.111 & 4.16 & 0.053 \\
\hline TE & 1.64 & 0.10 & 0.758 & 0.71 & 0.404 \\
\hline $\mathrm{PD} \times \mathrm{TE}$ & 2.63 & 6.98 & 0.012 & 0.07 & 0.791 \\
\hline \multicolumn{6}{|c|}{ Plant functional groups } \\
\hline $\mathrm{C}_{3}$ grasses & 1.64 & 0.25 & 0.622 & 0.43 & 0.519 \\
\hline $\mathrm{C}_{4}$ grasses & 1.64 & 0.39 & 0.537 & 1.43 & 0.245 \\
\hline Legumes & 1.64 & 0.91 & 0.352 & 0.03 & 0.873 \\
\hline Forbs & 1.64 & 0.79 & 0.383 & 0.01 & 0.924 \\
\hline Woody species & 1.64 & 0.03 & 0.860 & 0.13 & 0.721 \\
\hline Total error & $36,35^{\dagger}, 34^{\star}$ & & & & \\
\hline
\end{tabular}

Notes: Significant results $(P<0.05)$ are highlighted in bold and marginally significant results $(P<0.10)$ are given in bold and italics.

$\uparrow$ Phenol oxidase

† Urease.

diversity and warming (Table 2), but was increased in the presence of legumes in $2011(+74 \%)$. Additionally, mass-specific urease activity showed a significant decrease with increasing plant diversity (Fig. 3f; Appendix).

Microbial biomass and functions differed in 2011 and 2012. In 2011, PCA axis 1 explained $22.72 \%$, and PCA axis 2 explained $16.72 \%$ of the variation (Fig. 4a). Microbial biomass, microbial growth, and enzyme activities show no conclusive pattern. In 2012, microbial biomass and enzymes involved in the carbon cycle, i.e., 1,4- $\beta$-glucosidase, cellobiohydrolase, and 1,4- $\beta$-N-acetylglucosaminidase explained most of the variation (PCA axis 1: 31.89; Fig. 4b). Mainly plots with four and 16 plant species could be related to high 1,4- $\beta$-glucosidase, cellobiohydrolase, and 1,4$\beta$-N-acetylglucosaminidase activities, whereas most monocultures were associated with lower enzyme activity of these enzymes. PCA axis 2 correlated strongly with urease activity and explained $14.20 \%$. Plant diversity treatments and different temperature regimes were not clearly separated by PCA. However, in both years soil water content, soil microbial biomass, phosphatase, and 1,4- $\beta$-glucosidase activities correlated positively and were associated with higher plant diversity plots, whereas microbial growth after the addition of glucose showed the opposite pattern (Fig. 4 a, b).

\section{DisCUSSION}

In line with our expectations, plant diversity significantly influenced soil microbial functions in six out of twelve microbial responses (largely confirming one of our hypotheses). Soil microbial biomass increased significantly with increasing plant diversity in both years of the present study. These findings are consistent with previous studies reporting positive effects of plant diversity on soil microbial biomass and functions (e.g., Spehn et al. 2000, Eisenhauer et al. 2010). In those biodiversity experiments, plant shoot and root biomass (Reich et al. 2012) and, subsequently, soil carbon content increased substantially with plant diversity (Fornara and Tilman 2009). Therefore, higher availability of plant-derived resources have a strong and positive effect on soil microbial biomass (Wardle and Nicholson 1996, Chung et al. 2007). In the very sandy soils of the experiment with low availability of organic materials, the likely carbon-limitation for soil microorganisms (Eisenhauer et al. 2013) may have been ameliorated in species-rich plots compared to species-poor plots.

Microbial growth after nutrient addition of $\mathrm{CN}$ was decreased in the presence of $\mathrm{C}_{3}$ grasses, while $\mathrm{C}_{4}$ grasses had the opposite effect. $\mathrm{C}_{4}$ grasses are known to be more drought tolerant than $\mathrm{C}_{3}$ grasses (Tilman and Downing 1994). Thus, in the drier year (2012), $C_{4}$ grasses may have suffered less from low soil water content, thereby 
TABLE 2. Extended.

\begin{tabular}{|c|c|c|c|c|c|c|c|c|c|}
\hline \multicolumn{2}{|c|}{ 1,4-B-N-acetyl-glucosaminidase } & \multicolumn{2}{|c|}{ Phosphatase } & \multicolumn{2}{|c|}{ Peroxidase } & \multicolumn{2}{|c|}{ Phenol oxidase } & \multicolumn{2}{|c|}{ Urease } \\
\hline$F$ & $P$ & $F$ & $P$ & $F$ & $P$ & $F$ & $P$ & $F$ & $P$ \\
\hline 7.28 & 0.013 & 0.25 & 0.623 & 0.45 & 0.507 & 0.68 & 0.418 & 0.40 & 0.535 \\
\hline 0.72 & 0.400 & 0.97 & 0.331 & 2.20 & 0.147 & 8.07 & 0.007 & 0.76 & 0.389 \\
\hline 5.05 & $\mathbf{0 . 0 3 1}$ & 7.94 & 0.008 & 0.20 & 0.655 & 0.29 & 0.596 & 0.87 & 0.359 \\
\hline 0.43 & 0.521 & 0.03 & 0.863 & 0.13 & 0.718 & 0.11 & 0.743 & 0.35 & 0.562 \\
\hline 1.80 & 0.194 & 0.00 & 0.962 & 0.37 & 0.548 & 2.90 & 0.103 & 0.01 & 0.920 \\
\hline 0.20 & 0.656 & 0.10 & 0.756 & 8.39 & 0.008 & 0.00 & 0.962 & 3.02 & 0.096 \\
\hline 0.03 & 0.870 & 1.00 & 0.329 & 0.07 & 0.801 & 6.30 & 0.020 & 0.23 & 0.634 \\
\hline 0.02 & 0.892 & 1.13 & 0.299 & 3.06 & 0.094 & 0.28 & 0.602 & 0.02 & 0.883 \\
\hline 7.28 & 0.013 & 0.25 & 0.623 & 0.45 & 0.507 & 0.68 & 0.418 & 0.40 & 0.535 \\
\hline 0.72 & 0.400 & 0.97 & 0.331 & 2.20 & 0.147 & 8.07 & 0.007 & 0.76 & 0.389 \\
\hline 5.05 & 0.031 & 7.94 & 0.008 & 0.20 & 0.655 & 0.29 & 0.596 & 0.87 & 0.359 \\
\hline 0.43 & 0.521 & 0.03 & 0.863 & 0.13 & 0.718 & 0.11 & 0.743 & 0.35 & 0.562 \\
\hline 1.80 & 0.194 & 0.00 & 0.962 & 0.37 & 0.548 & 2.90 & 0.103 & 0.01 & 0.920 \\
\hline 0.20 & 0.656 & 0.10 & 0.756 & 8.39 & 0.008 & 0.00 & 0.962 & 3.02 & 0.096 \\
\hline 0.03 & 0.870 & 1.00 & 0.329 & 0.07 & 0.801 & 6.30 & 0.020 & 0.23 & 0.634 \\
\hline 0.02 & 0.892 & 1.13 & 0.299 & 3.06 & 0.094 & 0.28 & 0.602 & 0.02 & 0.883 \\
\hline
\end{tabular}

maintaining resource and nutrient availability for soil microorganisms.

In general, plant diversity and functional group composition significantly influenced microbial growth after the addition of nutrients confirming a previous study in another plant diversity experiment in grassland (Eisenhauer et al. 2010). Different plant diversity levels, plant communities, and availability of nutrients may have influenced soil microbial community structure (Zak et al. 2003), which may also have resulted in differential growth responses after addition of glucose, nitrogen, and phosphorus. Hence, soil microorganisms may have been limited by multiple nutrients, especially in highly diverse plant communities, and/or differences in growth may be caused by different microbial community compositions and growth strategies. This may have been due to nutrient competition between free-living soil microorganisms and plants (Kuzyakov and $\mathrm{Xu}$ 2013) and plant-associated microorganisms.

The results for soil microbial biomass and microbial growth are supported by significant effects of plant diversity on some soil enzymes, mostly on those involved in the $\mathrm{C}$ and $\mathrm{N}$ cycle. Higher activity of $\beta$-glucosidase (2011) and cellobiohydrolase (2012) in species-rich plant communities suggests greater availability of cellulose for soil microorganisms. Cellulose-degrading enzyme activities were found to be stimulated by the amount of substrate available and to coincide with an increasing dominance of heterotrophic fungi (Lynd et al. 2002). An adjacent plant diversity experiment (BioCON; Reich et al. 2001) reported similar results of increasing availabil- ity of cellulose with higher plant species richness (Chung et al. 2007). Increased 1,4- $\beta-\mathrm{N}$-acetylglucosaminidase activity, an enzyme involved in chitin degradation, also points to an increasing proportion of fungal biomass (Miller et al. 1998) in our experiment with higher plant diversity. As a result, 1,4- $\beta$-N-acetylglucosaminidase activity may be seen as an indicator of greater rates of chitin processed as carbon and nitrogen sources by numerous soil fungi and bacteria (Brzezinska et al. 2009). In addition to those single effects, the PCAs confirm associations between microbial biomass, enzymes involved in the $\mathrm{C}$ cycle, and soil water content (Fig. 4 a, b).

Warming decreased soil water content and had one significant and few marginally significant effects on soil enzyme activity (providing weak support for our second hypothesis). Although soil water content decreased significantly with increasing temperature in plant monocultures and four-species mixtures, we found little effects of warming on soil microbial biomass and growth. This finding is in contrast to our hypothesis and previous studies of decreasing microbial biomass due to temperature-induced reductions in soil moisture (Cole et al. 2002, Rinnan et al. 2007). Our findings are, however, consistent with a study by Tinker and Ineson (1990) who reported that temperature optima for soil organisms are sufficiently broad to buffer them against moderate changes in temperature $\left(1-5^{\circ} \mathrm{C}\right)$. This may be particularly so for soil microbial communities adapted to the sandy soil of the present experiment, which experiences large temperature and soil moisture fluctuations during 


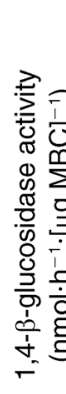

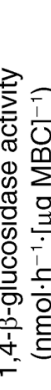

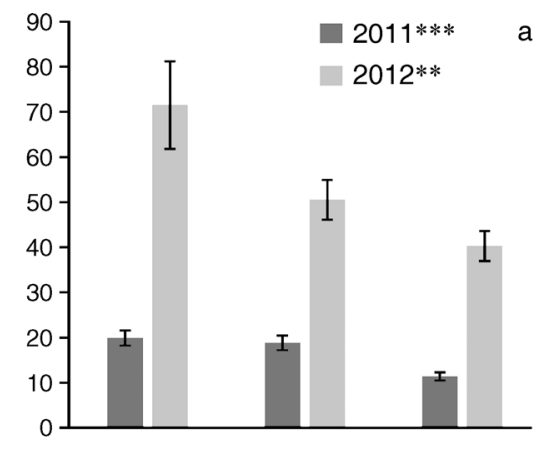

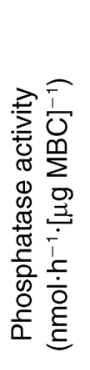
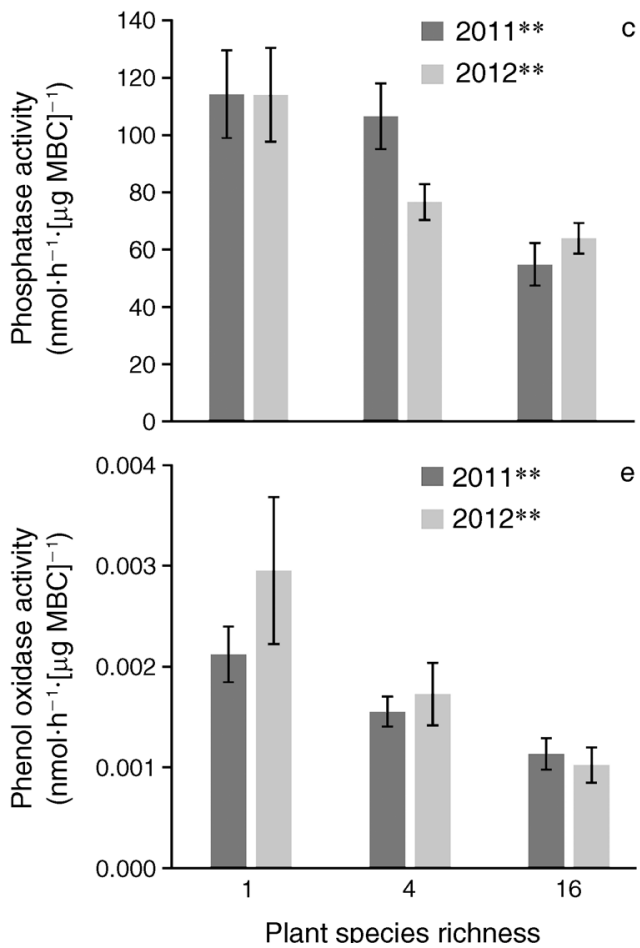
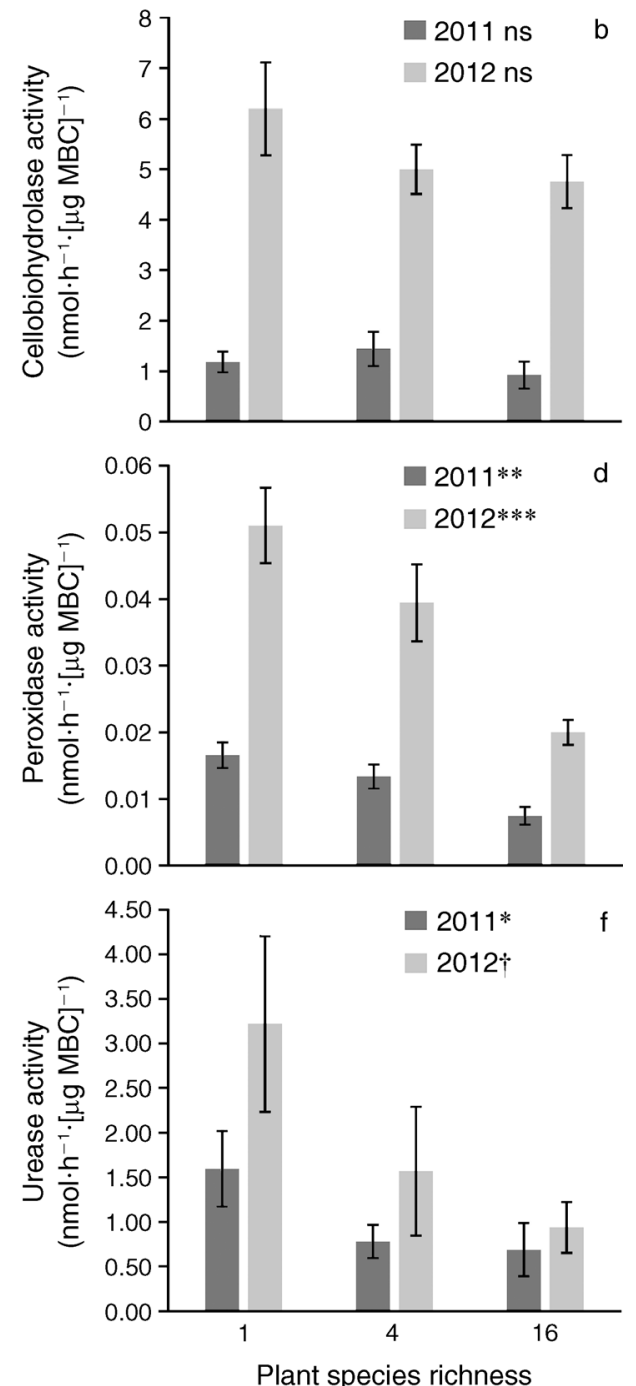

FIG. 3. Variations in mass-specific (a) 1,4-ß-glucosidase activity in 2011 (dark gray) and 2012 (light gray), (b) cellobiohydrolase activity, (c) phosphatase activity, (d) peroxidase activity, (e)phenol oxidase activity, and (f) urease activity (MBC, microbial biomass carbon) as affected by plant species richness (one, four, and 16 plant species). Values are means \pm SE.

*** $P<0.001 ; * * P<0.01 ; * P<0.05 ; \dagger P<0.1 ;$ ns, not significant.

summer months. Temperature and moisture are key determinants of soil microbial community composition and functions (Rustad et al. 2001, Baldrian et al. 2010), but they act in concert with many other factors. Flanagan and Johnson (2005) studied soil water and warming effects in northern temperate grassland and found stimulating effects on plant productivity. In the BAC experiment, plant biomass production increased significantly with plant diversity and temperature (J. Cowles, unpublished data). Our results suggest that plant diversity, as an important driver of plant productivity (Tilman 2001, Reich et al. 2012), the availability of organic material (Fornara and Tilman 2009), and therefore soil carbon quantity and quality (Hooper et al. 2000), was a major factor influencing soil microbial properties in the present experiment.
The amount of enzymes present at a certain time is a function of the rates of enzyme production and degradation (Geissler et al. 2011). Enzyme activity is further influenced by immobilization and inhibition (Burns et al. 2013). In soils with low soil water content, the degradation rate may be low because extracellular enzymes were immobilized by physically binding to organic matter, minerals, or microbial cell surfaces (Burns et al. 2013). Those soil-bound enzymes represent a significant reservoir of potential enzyme activity and may act as a first catalytic response to changes in nutrient and substrate availability. Notably, those soil colloid-enzyme complexes may also be a source of substrate turnover during periods of low microbial biomass due to stressed conditions (Stursova and Sinsabaugh 2008). Phenol oxidase, part of the 

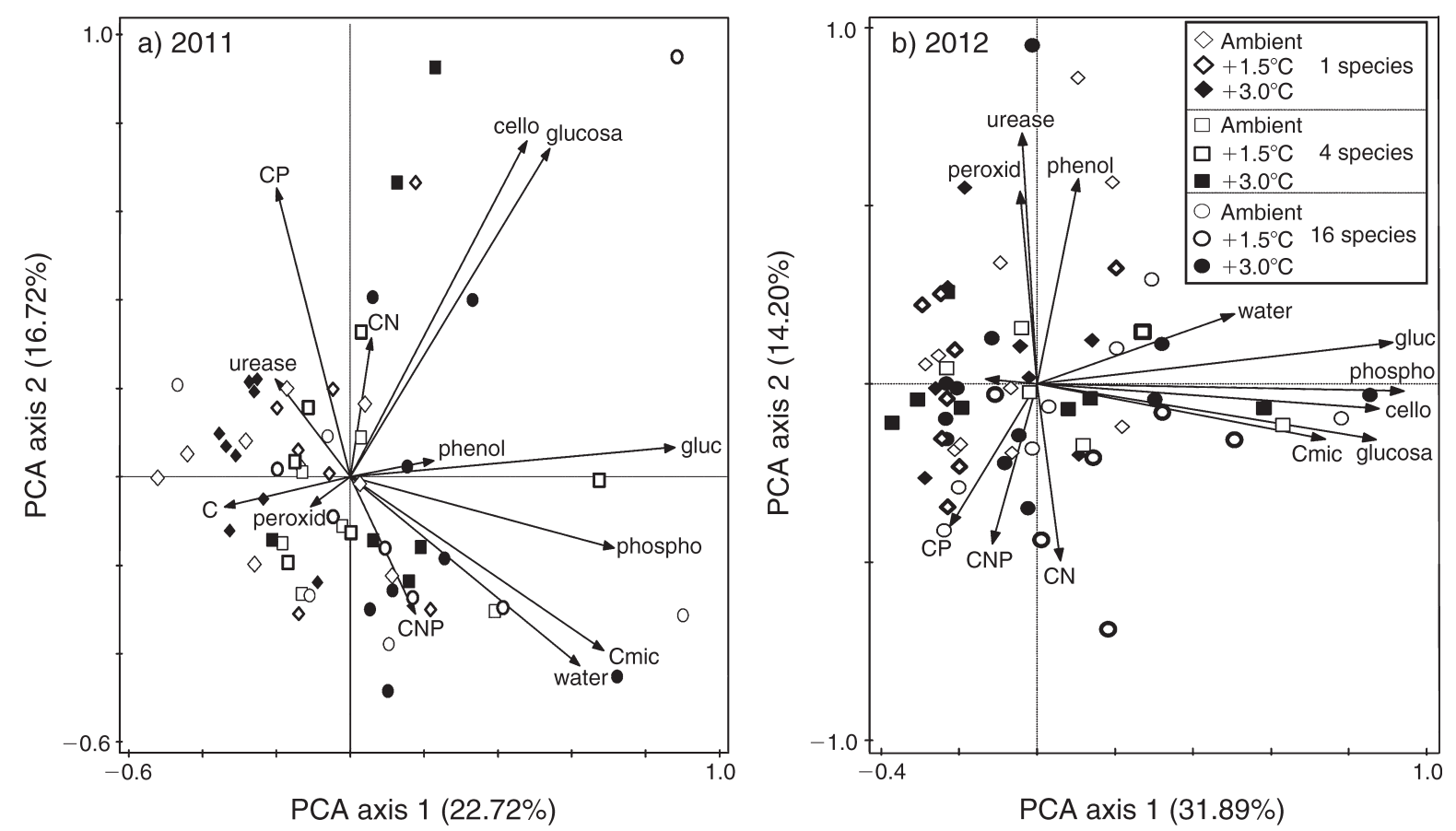

FIG. 4. Ordination diagram of principal component analyses of soil microbial biomass, microbial growth after nutrient additions, and soil enzyme activities as affected by plant diversity (one, four, and 16 plant species) and temperature treatment (ambient $+0^{\circ} \mathrm{C},+1.5^{\circ} \mathrm{C}$, and $+3^{\circ} \mathrm{C}$ ) in (a) 2011 (axes 1 and 2 account for $22.72 \%$ and $16.72 \%$ of the variation, respectively) and (b) 2012 (axes 1 and 2 account for $31.89 \%$ and $14.20 \%$ of the variation, respectively). Cmic stands for microbial biomass, C stands for microbial growth after addition of carbon, $\mathrm{CN}$ stands for microbial growth after addition of carbon and nitrogen, $\mathrm{CP}$ stands for microbial growth after addition of carbon and phosphorus, CNP stands for microbial growth after addition of carbon, nitrogen, and phosphorus, water stands for soil water content, gluc stands for 1,4-B-glucosidase activity, cello stands for cellobiohydrolase activity, glucose stands for 1,4-B-N-acetylglucosaminidase activity, phosphor stands for phosphatase activity, peroxid stands for peroxidase activity, phenol stands for phenol oxidase activity, and urease stands for urease activity.

soil $\mathrm{C}$ cycle in soil, depolymerizes lignin, detoxifies phenol moieties, and is mainly produced by specialized fungi and a few bacteria like actinomycetes (Keyser et al. 1978, Kirk and Farrell 1987). Its activity significantly increased with increasing temperature at higher soil water content in 2011, whereas the opposite was true at lower soil water content in 2012. This may be due to stimulated fungal growth in higher soil moisture conditions (Rousk and Bååth 2011). In 2012 , the temperature-induced decrease in soil moisture may have reduced phenol oxidase activity either due to reduced enzyme production as a result of soil microbial moisture stress or because of direct effects of low moisture on enzyme activity due to adsorption to mineral particles in soil (Toberman et al. 2008, Steinweg et al. 2012).

Soil water content significantly decreased with increasing temperature, but, as expected, only in plant communities with one and four species, whereas temperature did not affect soil water content in 16species mixtures. However, this interactive effect of plant diversity and temperature on soil water content did not propagate into soil microbial biomass and growth rates (contradicting our third hypothesis). Species-rich plant communities often may have moist- er topsoils than species-poor communities, due to reduced evaporation and a more stable and moist microclimate close to the soil surface (Caldeira et al. 2001, Rosenkranz et al. 2012, Eisenhauer et al. 2013). However, exceptions have been reported showing no effect of plant diversity on soil moisture (Spehn et al. 2000). In our experiment, species-rich plant assemblages did not buffer warming effects on soil microbial biomass and growth. However, enzyme activity of $\beta$-glucosidase (2011), 1,4- $\beta$-N-acetylglucosaminidase (2011), phosphatase (2011), and peroxidase (2012) showed no significant responses to warming in plant monocultures, whereas the activities increased in species-rich plant communities. Theoretically, climate warming will increase the rate of enzymatically catalyzed reactions due to an increasing kinetic energy up to an optimum of catabolic activity (Wallenstein and Weintraub 2008). On the other side, soil microorganisms may decrease enzyme synthesis and secretion due to warming (Allison 2005, Wallenstein et al. 2012). Taken together, a reduction of enzyme activity suggests either a decreased enzyme production per unit biomass or an increased in enzyme turnover (Burns et al. 2013). Our results showed a general trend of decreasing mass-specific enzyme activities with 


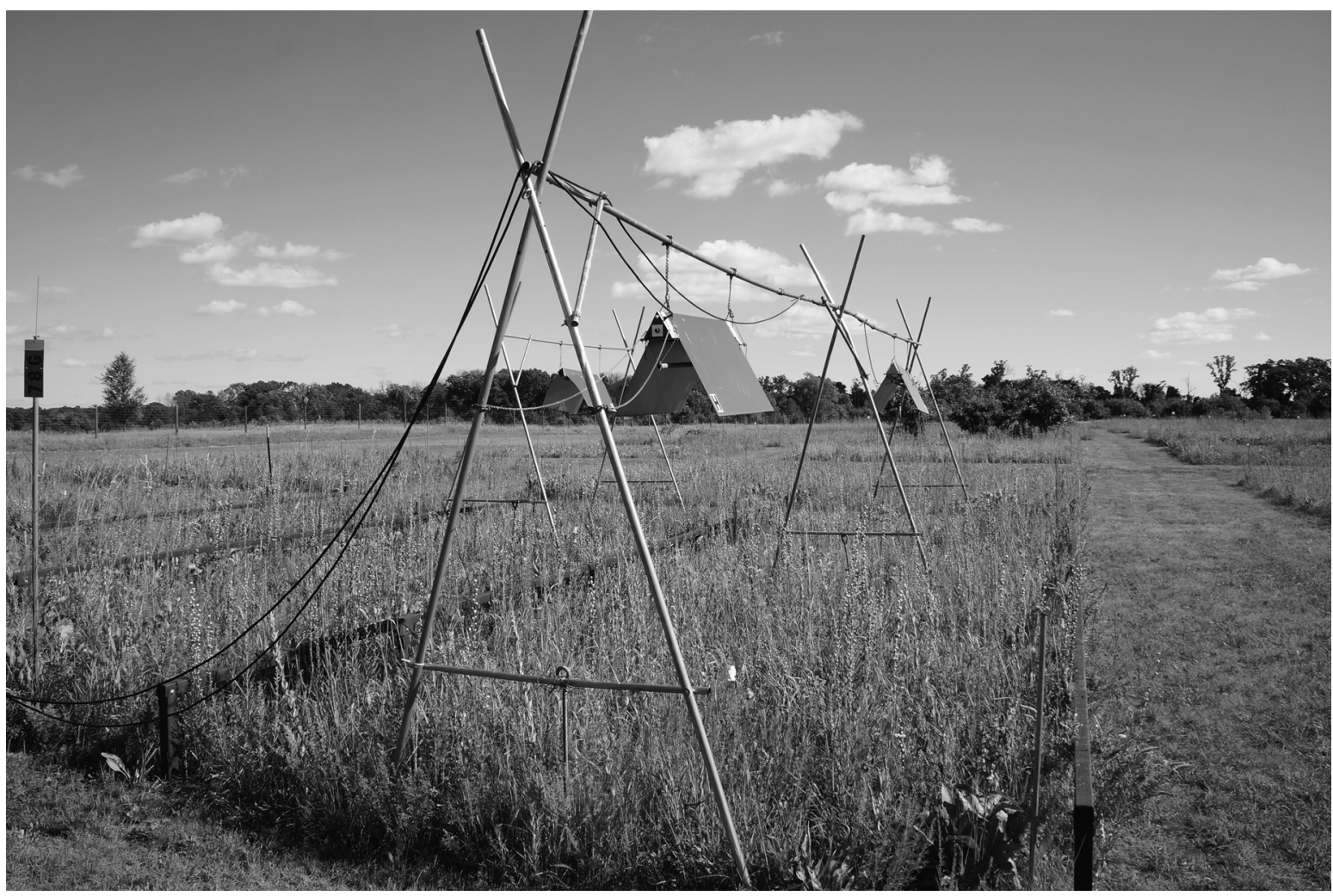

Plate 1. High plant diversity plot within the BAC experiment established at the Cedar Creek Ecosystem Science Reserve, Minnesota, USA, for studying warming effects on a grassland ecosystem. Metal flanges and frames with infrared lamps were hung over all subplots to increase the temperature by either $1.5^{\circ} \mathrm{C}$ or $3^{\circ} \mathrm{C}$, and hung as well as above control subplots to account for shading effects. Photo credit: K. Steinauer.

increasing plant diversity, thus suggesting compositional changes of soil microbial communities and/or changed resources along the plant diversity gradient. In contrast to our third hypothesis, plant diversity did not buffer but intensified effects of increasing temperature on the activity of some soil enzymes. Thus, changes in plant diversity may alter the magnitude of effects of other global change agents on ecosystem functions.

In conclusion, significant plant diversity effects on soil microbial biomass, growth, and enzyme activities in the $\mathrm{C}, \mathrm{N}$, and $\mathrm{P}$ cycle suggest that soil microorganisms and functions were likely driven by greater quantity and quality of plant-derived resources at high plant diversity and to a little extent affected by temperature changes. Our results further suggest that plant diversity can buffer ecosystem responses to increasing temperatures in some cases (here soil water content), but intensifies responses of other processes (several soil enzymes), complicating the prediction of interactive effects on ecosystem functioning. The loss of plant species to levels already prevalent in disturbed grassland in the study region (Eisenhauer et al. 2013) may impair essential soil microbial processes highlighting the vital role of plant biodiversity and aboveground-belowground interactions for ecosystem functioning.

\section{ACKNOWLEDGMENTS}

We thank Troy Mielke and many Cedar Creek interns for running the BAC (biodiversity and climate) experiment and taking the soil samples. Data used in this work was supported by the National Science Foundation NSF/DEB-1234162. Katja Steinauer and Nico Eisenhauer acknowledge funding by the Deutsche Forschungsgemeinschaft (DFG; Ei 862/1, Ei 862/2). We would like to thank two anonymous reviewers for their helpful comments, which considerably improved the manuscript. We also appreciate the suggestions on statistics by Madhav Prakash Thakur.

\section{Literature Cited}

Allison, S. D. 2005. Cheaters, diffusion and nutrients constrain decomposition by microbial enzymes in spatially structured environments. Ecology Letters 8:626-635.

Allison, S. D., M. N. Weintraub, T. B. Gartner, and M. P. Waldrop. 2011. Evolutionary-economic principles as regulators of soil enzyme production and ecosystem function. Pages 229-243 in G. Shukla and A. Varma, editors. Soil Enzymology. Springer-Verlag, Berlin, Germany.

Anderson, J. M., and K. H. Domsch. 1978. A physiological method for the quantitative measurement of microbial biomass in soils. Soil Biology and Biochemistry 10:215221.

Baldrian, P., V. Merhautová, M. Petránková, T. Cajthaml, and J. Šnajdr. 2010. Distribution of microbial biomass and activity of extracellular enzymes in a hardwood forest soil reflect soil moisture content. Applied Soil Ecology 46:177182. 
Baldrian, P., and V. Valaškova. 2008. Degradation of cellulose by basidiomycetous fungi. FEMS Microbiology Reviews 32: 501-521.

Brzezinska, M. S., E. Lalke-Porczyk, W. Donderski, and M. Walczak. 2009. Degradation of chitin in natural environment: role of actinomycetes. Polish Journal of Ecology 57: 229-238.

Burns, R. G. 1982. Enzyme activity in soil: location and a possible role in microbial ecology. Soil Biology and Biochemistry 14:423-427.

Burns, R. G., et al. 2013. Soil enzymes in a changing environment: current knowledge and future directions. Soil Biology and Biochemistry 58:216-234.

Butenschoen, O., S. Scheu, and N. Eisenhauer. 2011. Interactive effects of warming, soil humidity and plant diversity on litter decomposition and microbial activity. Soil Biology and Biochemistry 43:1902-1907.

Caldeira, M. C., R. J. Ryel, J. H. Lawton, and J. S. Periera. 2001. Mechanisms of positive biodiversity-production relationships: insights provided by $\delta^{13} \mathrm{C}$ analysis in experimental Mediterranean grassland plots. Ecology Letters 4:439-443.

Cardinale, B. J., et al. 2011. The functional role of producer diversity in ecosystems. American Journal of Botany 98:572592.

Chung, H., D. R. Zak, P. B. Reich, and D. S. Ellsworth. 2007. Plant species richness, elevated $\mathrm{CO}_{2}$, and atmospheric nitrogen deposition alter soil microbial community composition and function. Global Change Biology 13:1-10.

Cole, L., R. D. Bardgett, P. Ineson, and P. J. Hobbs. 2002. Enchytraeid worm (Oligochaeta) influences on microbial community structure, nutrient dynamics and plant growth in blanket peat subjected to warming. Soil Biology and Biochemistry 34:83-92.

de Valpine, P., and J. Harte. 2001. Effects of warming on a montane meadow ecosystem: how species responses comprise the ecosystem response. Ecology 82:637-648.

Eisenhauer, N., S. Cesarz, R. Koller, K. Worm, and P. B. Reich. 2012. Global change below ground: impacts of elevated $\mathrm{CO}_{2}$, nitrogen and summer drought on soil food webs and biodiversity. Global Change Biology 18:435-447.

Eisenhauer, N., et al. 2010. Plant diversity effects on soil microorganisms support the singular hypothesis. Ecology 91: 485-496.

Eisenhauer, N., et al. 2013. Plant diversity effects on soil food webs are stronger than those of elevated $\mathrm{CO}_{2}$ and $\mathrm{N}$ deposition in a long-term grassland experiment. Proceedings of the National Academy of Sciences USA 110:6889-6894.

Flanagan, L. B., and B. G. Johnson. 2005. Interacting effects of temperature, soil moisture and plant biomass production on ecosystem respiration in a northern temperate grassland. Agricultural and Forest Meteorology 130:237-253.

Fornara, D. A., and D. Tilman. 2009. Ecological mechanisms associated with the positive diversity-productivity relationship in an N-limited grassland. Ecology 90:408-418.

Geisseler, D., W. R. Horwath, and K. M. Scow. 2011. Soil moisture and plant residue addition interact in their effect on extracellular enzyme activity. Pedobiologia 54:71-78.

German, D. P., S. S. Chacon, and S. D. Allison. 2011. Substrate concentration and enzyme allocation can affect rates of microbial decomposition. Ecology 92:1471-1480.

Hooper, D. U. 2012. A global synthesis reveals biodiversity loss as a major driver of ecosystem change. Nature 486:105-108.

Hooper, D. U., et al. 2000. Interactions between aboveground and belowground biodiversity in terrestrial ecosystems: patterns, mechanisms, and feedbacks. BioScience 50:10491061.

IPCC. 2013. Climate change 2013: the physical science basis. In S. Solomon, D. Qin, M. Manning, Z. Chen, M. Marquis, K. B. Averyt, M. Tignor, and H. L. Miller, editors. Cambridge University Press, New York, New York, USA.
Ives, A. R., and R. S. Carpenter. 2007. Stability and diversity of ecosystems. Science 317(5834):58-62.

Kandeler, E., D. Tscherko, and H. Spiegel. 1999. Long-term monitoring of microbial biomass, $\mathrm{N}$ mineralization and enzyme activities of a Chernozem under different tillage management. Biology and Fertility of Soils 28:343-351.

Keyser, P., T. K. Kirk, and J. G. Zeikus. 1978. Ligninolytic enzyme system of Phanerochaetechrysosporium: synthesized in the absence of lignin in response to nitrogen starvation. Journal of Bacteriology 135:790-797.

Kimball, B. A. 2005. Theory and performance of an infrared heater for ecosystem warming. Global Change Biology 11: 2041-2056.

Kirk, T. K., and R. L. Farrel. 1987. Enzymatic combustion: the microbial degradation of lignin. Annual Review of Microbiology 41:465-505.

Kuzyakov, Y., and X. Xu. 2013. Competition between roots and microorganisms for nitrogen: mechanisms and ecological relevance. New Phytologist 198:656-669.

Larsen, K. S., et al. 2010. Reduced N cycling in response to elevated $\mathrm{CO}_{2}$, warming, and drought in a Danish heathland: synthesizing results of the CLIMATE project after two years of treatments. Global Change Biology 17:1884-1899.

Lepš, J., and P. Šmilauer. 2003. Multivariate analysis of ecological data using CANOCO. First edition. Cambridge University Press, Cambridge, UK.

Liski, J., A. Nissinen, M. Erhard, and O. Taskinen. 2003. Climatic effects on litter decomposition from arctic tundra to tropical rainforest. Global Change Biology 9:575-584.

Lynd, L. R., P. J. Weimer, W. H. van Zyl, and I. S. Pretorius. 2002. Microbial cellulose utilization: fundamentals and biotechnology. Microbiology and Molecular Biology Reviews 66:506-577.

Melillo, J. M., et al. 2002. Soil warming and carbon-cycle feedbacks to the climate system. Science 298:2173-2176.

Miller, S. S., B. T. Driscoll, R. G. Gregerson, J. S. Gantt, and C. P. Vance. 1998. Alfalfa malate dehydrogenase MDH: molecular cloning and characterization of five different forms reveals a unique nodule-enhanced MDH. Plant Journal 15: 173-184.

R Development Core Team. 2013. R: a language and environment for statistical computing. R Foundation for Statistical Computing, Vienna, Austria. http://www. R-project.org/

Reich, P. B., D. Tilman, F. Isbell, K. Mueller, S. E. Hobbie, D. F. B. Flynn, and N. Eisenhauer. 2012. Impacts of biodiversity loss escalate through time as redundancy fades. Science 336:589-592.

Reich, P. B., et al. 2001. Plant diversity enhances ecosystem responses to elevated $\mathrm{CO}_{2}$ and nitrogen deposition. Nature 410:809-810.

Rinnan, R., A. Michelsen, E. Baath, and S. Jonasson. 2007. Fifteen years of climate change manipulations alter soil microbial communities in a subarctic heath ecosystem. Global Change Biology 13:28-39.

Rosenkranz, S., W. Wilcke, N. Eisenhauer, and Y. Oelmann. 2012. Net ammonification as influenced by plant diversity in experimental grasslands. Soil Biology and Biochemistry 48: $78-87$.

Rousk, J., and E. Bååth. 2011. Growth of saprotrophic fungi and bacteria in soil. FEMS Microbiology Ecology 78:17-30.

Rustad, L. E., et al. 2001. A meta-analysis of the response of soil respiration, net nitrogen mineralization, and aboveground plant growth to experimental ecosystem warming. Oecologia 126:543-562.

Saiya-Cork, K. R., R. L. Sinsabaugh, and D. R. Zak. 2002. The effects of long term nitrogen deposition on extracellular enzyme activity in an Acer saccharum forest soil. Soil Biology and Biochemistry 34:1309-1315.

Saleska, S. R., M. B. Shaw, and M. L. Fischer. 2002. Plant community composition mediates both large transient decline 
and predicted long-term recovery of soil carbon under climate warming. Global Biogeochemical Cycles 16:1055.

Sanaullah, M., E. Blagodatskaya, A. Chabbi, C. Rumpel, and Y. Kuzyakov. 2011. Drought effects on microbial biomass and enzyme activities in the rhizosphere of grasses depend on plant community composition. Applied Soil Ecology 48:3844.

Scheu, S. 1992. Automated measurement of the respiratory response of soil microcompartments: active microbial biomass in earthworm faeces. Soil Biology and Biochemistry 24: $1113-1118$.

Schindlbacher, A., et al. 2012. Soil respiration under climate change: prolonged summer drought offsets soil warming effects. Global Change Biology 18:2270-2279.

Sinsabaugh, R. L. 1994. Enzymic analysis of microbial pattern and process. Biology and Fertility of Soils 17:69-74.

Sinsabaugh, R. L., B. H. Hill, and J. J. Follstad Shah. 2009. Ecoenzymatic stoichiometry of microbial organic nutrient acquisition in soil and sediment. Nature Reviews Microbiology 462:795-799.

Sørensen, J. 1997. The rhizosphere as a habitat for soil microorganisms. Page 26 in J. D. V. Elsas, J. T. Trevors, E. M. K. Wellington, editors. Modern soil microbiology. Marcel Dekker, New York, New York, USA.

Spehn, E. M., J. Joshi, B. Schmid, J. Alphei, and C. Körner. 2000. Plant diversity effects on soil heterotrophic activity in experimental grassland ecosystems. Plant and Soil 224:217230.

Stark, J. M., and M. K. Firestone. 1995. Mechanisms for soil moisture effects on activity of nitrifying bacteria. Applied and Environmental Microbiology 61:218-221.

Steinweg, J. M., J. Dukes, and M. D. Wallenstein. 2012. Modeling the effects of temperature and moisture on soil enzyme activity: linking laboratory assays to continuous field data. Soil Biology and Biochemistry 55:85-92.

Stone, M. M., et al. 2012. Temperature sensitivity of soil enzyme kinetics under $\mathrm{N}$-fertilization in two temperate forests. Global Change Biology 18:1173-1184.

Stursova, M., and R. L. Sinsabaugh. 2008. Stabilization of oxidative enzymes in desert soil may limit organic matter accumulation. Soil Biology and Biochemistry 40:550-553.

Tilman, D., and J. A. Downing. 1994. Biodiversity and stability in grasslands. Nature 367:363-364.

Tilman, D., J. Hill, and C. Lehman. 2006. Carbon-negative biofuels from low-input high-diversity grassland biomass. Science 314:1598-1600.

Tilman, D., et al. 2001. Diversity and productivity in a longterm grassland experiment. Science 294:843-845.

Tinker, P. B., and P. Ineson. 1990. Soil organic matter and biology in relation to climate change. Pages 71-88 in H. W. Scharpenseel, M. Schomaker, A. Ayoub, editors. Soils on a warmer earth. Developments in soil science. Volume 20. Elsevier Science, Amsterdam, The Netherlands.

Toberman, H. T., C. Freeman, C. Evans, C. Fenner, and R. R. E. Artz. 2008. Enhanced summer droughts decrease soil fungal diversity and inhibit fungal associated extracellular phenol oxidase activity in upland Calluna heathland soil. FEMS Microbiology Ecology 66:426-436.

van der Heijden, M. G. A., R. D. Bardgett, and N. M. van Straalen. 2008. The unseen majority: soil microbes as drivers of plant diversity and productivity in terrestrial ecosystems. Ecology Letters 11:296-310.

Vogel, A., M. Scherer-Lorenzen, and A. Weigelt. 2012. Grassland resistance and resilience after drought depends on management intensity and species richness. PLoS ONE 7(5):e36992.

Wallenstein, M. D., M. L. Haddix, D. D. Lee, R. T. Conant, and E. A. Paul. 2012. A litter-slurry technique elucidates the key role of enzyme production and microbial dynamics in temperature sensitivity of organic matter decomposition. Soil Biology and Biochemistry 47:18-26.

Wallenstein, M. D., S. K. McMahon, and J. P. Schimel. 2009. Seasonal variation in enzyme activities and temperature sensitivities in Arctic tundra soils. Global Change Biology 15: 1631-1639.

Wallenstein, M. D., and M. N. Weintraub. 2008. Emerging tools for measuring and modeling the in situ activity of soil extracellular enzymes. Soil Biology and Biochemistry 40: 2098-2106.

Wan, S., Y. Luo, and L. L. Wallace. 2002. Change in microclimate induced by experimental warming and clipping in tallgrass prairie. Global Change Biology 8:754-768.

Wardle, D. A., and K. S. Nicholson. 1996. Synergistic effects of grassland plant species on soil microbial biomass and activity: implications for ecosystem-level effects of enriched plant diversity. Functional Ecology 10:410-416.

Wardle, D. A., et al. 2004. Ecological linkages between aboveground and belowground biota. Science 304:16291633.

Weltzin, J. F., S. D. Bridgham, J. Pastor, J. Chen, and C. Hart. 2003. Potential effect of warming and drying on peatland plant community composition. Global Change Biology 9: 141-151.

Whittington, H. R., D. Tilman, and J. S. Powers. 2013. Consequences of elevated temperatures on legume biomass and nitrogen cycling in a field warming and biodiversity experiment in a North American prairie. Functional Plant Biology 40(11):1147-1158.

Zak, D. R., W. E. Holmes, D. C. White, A. D. Peacock, and D. Tilman. 2003. Plant diversity, soil microbial communities, and ecosystem function: are there any links? Ecology 84: 2042-2050.

Zaller, J. G., and J. A. Arnone. 1997. Activity of surface-casting earthworms in a calcareous grassland under elevated atmospheric $\mathrm{CO}_{2}$. Oecologia 111:249-254.

Zhang, W., K. M. Parker, Y. Luo, S. Wan, L. L. Wallace, and S. Hu. 2005. Soil microbial responses to experimental warming and clipping in a tallgrass prairie. Global Change Biology 11:266-277.

\section{Supplemental Material}

\section{Ecological Archives}

The Appendix and Supplement are available online: http://dx.doi.org/10.1890/14-0088.1.sm 